\title{
Perencanaan Ulang LRT JABODEBEK Lintas Pelayanan 3 (Cawang-Bekasi Timur) dengan Modifikasi Alinyemen Ditinjau dari Segi Kelayakan Ekonomi dan Finansial
}

\author{
Muhammad Adnan dan Wahju Herijanto \\ Departemen Teknik Sipil, Fakultas Teknik Sipil, Lingkungan dan Kebumian, \\ Institut Teknologi Sepuluh Nopember (ITS) \\ e-mail: herijanto@ce.its.ac.id
}

\begin{abstract}
Abstrak-Dalam perencanaan LRT Jabodebek Cawang - Bekasi Timur dibutuhkan Analisis kelayakan aspek ekonimi dan finansial sebagai bahan pertimbangan dalam investasi agar proyek LRT Jabodebek Cawang - Bekasi Timur menjadi efisien. Dengan dilaksanakannya Analisis tersebut didapatkan nilai penghematan Biaya Operasional Kendaraan (BOK) dan nilai waktu sebelum dan sesudah adanya LRT Jabodebek Cawang Bekasi Timur. Sehingga akan diketahui kelayakan pembanguan LRT dari segi finansial dan ekonomi. Lalu akan dilakukan perencaan alinyemen jalur LRT Cawang - Bekasi Timur dengan menggunakan rute alternatif. Metodologi untuk menganalisis Biaya Operasional Kendaraan (BOK) dan nilai waktu menggunakan metode Jasa Marga. Untuk menganalisis aspek kelayakan ekonomi menggunakan parameter BCR dan NPV sebagai acuan kelayakan. Sedangkan untuk menganalisis aspek kelayakan finansial menggunakan parameter BCR, NPV, dan IRR sebagai acuan kelayakan. Dari analisis aspek ekonomi didapatkan penghematan BOK dan nilai waktu sebesar Rp. 48.748.436.625.973 sehingga didapatkan nilai BCR sebesar 5,11 > 1 dan nilai NPV sebesar Rp. Rp39.208.173.411.349 > 1. Sementara dari analisis aspek finansial didapatkan pendapatan dari penjualan tiket LRT sebesar Rp. 18.359.007.303.801 sehingga didapatkan nilai BCR sebesar 1,84 > 1 dan nilai NPV sebesar Rp. 8.818.744.089.177 > 1 dan nilai IRR sebesar $10,98 \%>7,25 \%$. Maka dapat disimpulkan pembanguan LRT Jabodebek (Cawang - Bekasi Timur) layak secara finansial dan ekonomi. Sehingga dapat dilanjutkan dengan perencanaan alinyemen pada rute alternatif.
\end{abstract}

Kata Kunci-LRT, Light Rail Transit, Studi Kelayakan, Ekonomi, Finansial, Perencanaan Alinyemen.

\section{PENDAHULUAN}

$\mathrm{S}_{\mathrm{J}}^{\mathrm{E}}$ EIRING berkembangnya pertumbuhan penduduk di DKI Jakarta, mobilitas penumpang maupun barang di wilayah DKI Jakarta juga meningkat. Dibuktikan dengan jumlah kendaraan bermotor yang melewati jalan-jalan di ibukota Jakarta yang setiap tahun terus meningkat. Jumlah kendaraan bermotor tidak termasuk kendaraan TNI, Polri dan Corps Diplomatic di DKI Jakarta dari tahun ke tahun senantiasa mengalami kenaikan. Tingkat pertumbuhan kendaraan bermotor mencapai $9,93 \%$ per tahun, hal inilah salah satu penyebabkan tingkat kemacetan di DKI Jakarta semakin tinggi [1].

Kemacetan di DKI Jakarta disebabkan oleh kendaraan yang datang dari daerah di sekitar Jakarta, yaitu Bogor, Bekasi, Tanggerang, dan Depok. Pada data yang diolah oleh Badan Pengelola Transportasi Jabodetabek (BPTJ), ada 47,5 Juta perjalanan per hari di wilayah Jabodetabek dimana di wilayah DKI Jakarta ada $40 \%$ warga yang melakukan perjalanan dan sisanya berasal dari luar DKI Jakarta [1]. Selain masalah banyaknya jumlah kendaraan yang melakukan perjalanan dan tingginya jumlah kendaraan, sarana transportasi umum yang ada saat ini dirasa masih belum mempunyai tingkat keamanan dan kenyamanan yang memadai.

Pemerintah dalam hal ini Departemen Perhubungan berusaha menanggulanginya dengan membangun Light Rail Transit (LRT) Jabodebek. LRT Jabodebek diharapkan mampu mengurangi kepadatan kendaraan di jalan dan mengalihkan masyarakat yang menggunakan kendaraan pribadi ke transportasi massal terutama masyarakat yang berasal dari daerah di sekitar Jakarta. Jalur LRT Jabodebek terdiri dari Lintas Pelayanan 1 (Cawang-Cibubur), Lintas Pelayanan 2 (Cawang-Bekasi), dan Lintas Pelayanan 3 (Cawang-Dukuh Atas).

Dalam Studi ini akan dilakukan Perencanaan Geometrik proyek LRT Jabodebek (Light Rail Transit) Lintas Pelayanan 3 (Cawang - Bekasi Timur) dan Analisa Kelayakan finansial dan ekonomi yang akan membentang kurang lebih 18,5 km. Untuk mengetahui seberapa layak LRT Jabodebek dan bagaimana perkembangan ekonomi warga Jakarta dan Bekasi Timur maka dilakukan analisis kelayakan fianansial dan ekonomi. Perencanaan Alinyemen dilakukan untuk mengetahui apakah jika dilakuakan perubahan rute LRT melewati dalam kota akan lebih efisien dikarenakan akses menuju stasiun akan lebih mudah. Lintas layanan 3 dibagi menjadi 5 (Lima) segmen yaitu: Cawang - Jaticempaka, Jaticempaka - Cikunir, Cikunir Cikuni2, Cikunir2 - Bekasi Barat dan Bekasi Barat - Bekasi Timur. 
II. METODOLOGI

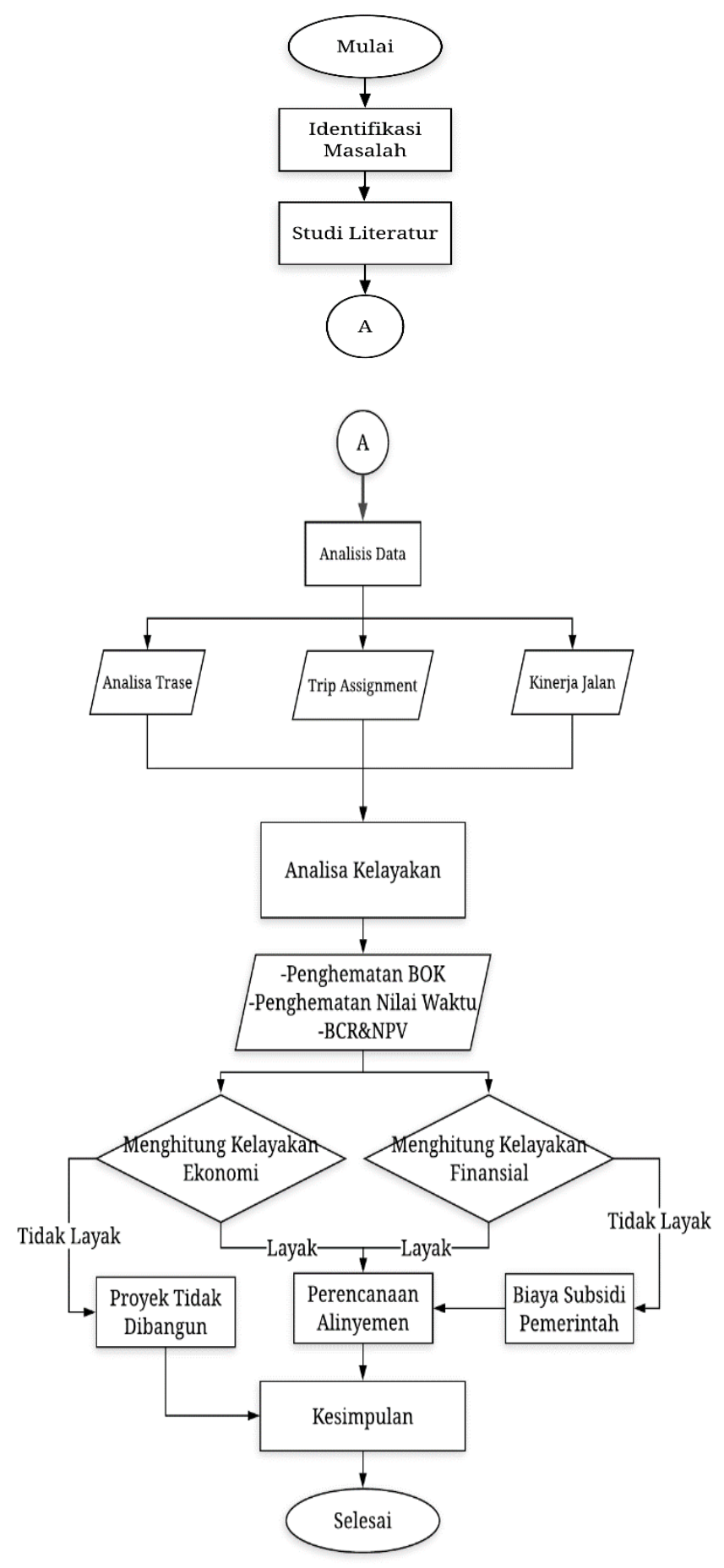

Gambar 1. Bagan Diagram Alir (Flow Chart).

\section{HASIL PEMBAHASAN}

\section{A. Analisis Data Lalu lintas}

Dari data traffic counting yang dilakukan oleh Jasamarga selaku pengelola jalan Tol Jakarta - Cikampek akan digunakan untuk beberapa analisis, antara lain kapasitas ruas, volume kendaraan, dan derajat kejenuhan.

Berikut hasil rekapitulasi volume lalu lintas harian pada setiap ruas:
Tabel 1.

Volume Kendaraan

\begin{tabular}{lr}
\hline \hline \multicolumn{1}{c}{ Gerbang Tol } & \multicolumn{2}{c}{ Volume Kendaraan } \\
\cline { 2 - 3 } & Total (Kendaraan/Hari) \\
\hline Cawang - Pd. Gede Barat & 14624 \\
Cawang - Pd. Gede Timur & 1182 \\
Cawang - Cikunir & 12919 \\
Cawang - Bekasi Barat & 1236 \\
Cawang - Bekasi Timur & 9664 \\
Cawang - Cikampek & 891 \\
Pd. Gede barat - Pd. Gede Timur & 1298 \\
Pd. Gede barat - Cikunir & 14183 \\
Pd. Gede Barat - Bekasi Barat & 1356 \\
Pd. Gede Barat - Bekasi Timur & 508 \\
Pd. Gede Barat - Cikampek & 995 \\
Cikunir - Bekasi Barat & 11668 \\
Cikunir - Bekasi Timur & 4358 \\
Cikunir - Cikampek & 995 \\
Bekasi Barat - Bekasi Timur & 4431 \\
Bekasi Barat - Cikampek & 8697 \\
Bekasi Timur - Cikampek & 90101 \\
Cikampek - Bekasi Timur & 29295 \\
Cikampek - Bekasi Barat & 23838 \\
Cikampek - Cikunir & 12809 \\
Cikampek - Pd Gede Barat & 9238 \\
Cikampek - Cawang & 30968 \\
Bekasi Timur - Bekasi Barat & 3959 \\
Bekasi Timur - Cikunir & 2129 \\
Bekasi Timur - Pd. Gede Barat & 1536 \\
Bekasi Timur - Cawang & 5144 \\
Bekasi Barat - Cikunir & 3084 \\
Bekasi Barat - Pd. Gede barat & 2225 \\
Bekasi Barat - Cawang & 7455 \\
Cikunir - Pd. Gede Barat & 3050 \\
Cikunir - Cawang & 10222 \\
Pd. Gede Timur - Pd Gede Barat & 300 \\
Pd. Gede Timur - Cawang & 338623 \\
Pd. Gede Barat - Cawang & \\
Total & \\
\hline \hline & \\
\hline & \\
\hline
\end{tabular}

Kapasitas didefinisikan sebagai arus maksimum yang melewati suatu titik pada jalan bebas hambatan yag dapat dipertahankan persatuan jam dalam kondisi yang berlaku [2]. Berikut adalah persamaan umum untuk menghitung kapasitas jalan menurut Pedoman Kapasitas Jalan Indonesia (PKJI) Tahun 2014 untuk jalan bebas hambatan:

$$
\mathrm{C}=\mathrm{C} 0 \times \mathrm{FC}_{L}
$$

Keterangan:

$\mathrm{C}=$ kapasitas $(\mathrm{skr} / \mathrm{jam})$

$\mathrm{C}_{0}=$ Kapasitas dasar (skr/jam)

FCLE $=$ Faktor penyesuaian akibat lebar jalur lalu lintas

Dikarenakan jalan di Tol Jakarta - Cikampek memiliki jumlah lajur yang sama dan lebar jalur yang sama maka kapasitas disetiap ruas jalan Tol Jakart - Cikampek sama. Sehingga didapatkan nilai kapasitas ruas dari masing-masing jalan eksisting sebagai berikut :

Tabel 2.

Kapasitas Ruas Jalan Tol Jakarta - Cikampek

\begin{tabular}{cccc}
\hline \hline \multicolumn{4}{c}{ Kapasitas Jalan Tol } \\
\hline Kapasitas dasar (C0) & 2300 (smp/jam)(per lajur) \\
$\begin{array}{c}\text { Tol Jakarta - Cikampek } \\
(8 / 2)\end{array}$ & Faktor Lebar Efektif (FClj) & 1 & \\
& Kapasitas (C) & 9200 & $(\mathrm{smp} / \mathrm{jam})$ \\
\hline \hline
\end{tabular}


Nilai derajat kejenuhan (DJ) menunjukkan kepadatan atau tingkat kemacetan suatu jalan. DJ dihitung menggunakan persamaan berikut:

$$
\mathrm{DJ}=\frac{\mathrm{Q}}{\mathrm{C}}
$$

Keterangan:

DJ = Derajat Kejenuhan Jalan

$\mathrm{Q}=$ Arus lalu lintas (skr/jam)

$\mathrm{C}=$ Kapasitas (skr/jam)

Sehingga didapatkan nilai derajat kejenuhan dari masingmasing ruas adalah sebagai berikut :

Tabel 3.

Nilai Derajat Kejenuhan

\begin{tabular}{cccc}
\hline \hline Ruas & Arus (Q) & Kapasitas (C) & Dj \\
\hline Ruas Cawang - Pd Gede Barat & 4616 & 9200 & 0.502 \\
Ruas Pd Gede Barat - Pd Gede Timur & 5016 & 9200 & 0.545 \\
Ruas Pd Gede Timur - Cikunir & 4739 & 9200 & 0.515 \\
Ruas Cikunir - Bekasi Barat & 3641 & 9200 & 0.396 \\
Ruas Bekasi Barat - Bekasi Timur & 3573 & 9200 & 0.388 \\
Ruas Bekasi Timur - Bekasi Barat & 10280 & 9200 & 1.117 \\
Ruas Bekasi Barat - Cikunir & 8557 & 9200 & 0.930 \\
Ruas Cikunir - Pd Gede Timur & 8042 & 9200 & 0.874 \\
Ruas Pd Gede Timur -Pd Gede Barat & 8190 & 9200 & 0.890 \\
Ruas Pd Gede Barat - Cawang & 7891 & 9200 & 0.858 \\
\hline \hline
\end{tabular}

\section{B. Analisa Trip Assignment}

Perhitungan trip assignment didapatkan dari demand masyarakat yang telah dihitung dari penelitian yang sudah ada. Penelitian yang diambil untuk studi ini harus berhubungan dengan LRT.

Hasil dari survey demand LRT di Korea adalah 22\% [3] dan untuk survey yang dilakukan UITP di negara india pada tahun 1997, jumlah pengendara mobil yang berpindah menggunakan LRT terdapat $11 \%$ [4].

Hasil perhitungan demand di kedua penelitian tersebut akan diinterpolasi sesuai dengan peringkat PPP (Purcase Power Purity) sehingga angka yang dipakai sebagai Trip Assignment pada studi ini adalah $12,77 \%$. Volume kendaraan yang dikurangi adalah volume kendaraan golongan I.

\section{Analisa Biaya Operasional Kendaraan}

Besarnya BOK dihitung per $1000 \mathrm{Km}$ dari berbagai golongan dan kecepatan dengan memasukkan harga dari masing- masing komponen dari tiap jenis kendaraan pada rumus perhitungan BOK. Perhitungan BOK dilakukan menggunakan metode Bina Marga. Berikut ini merupakan contoh perhitungan BOK untuk jalan eksisting.

a. Konsumsi Bahan Bakar

Konsumsi BBM = Konsumsi BBM dasar $[1+(k k+k l+k r)]$

Konsumsi BBM dasar dalam liter $1000 \mathrm{~km}$, sesuai golongan:

Gol I $=69,3224$ liter $/ 1000 \mathrm{~km}$

Gol IIa $=157,038$ liter $/ 1000 \mathrm{~km}$

Gol IIb $=201,593$ liter $/ 1000 \mathrm{~km}$

Konsumsi BBM (Rp/1000 km):

Konsumsi BBM $(\mathrm{Rp} / 1000 \mathrm{~km})=$ Konsumsi BBM dasar * $[1+$ $(\mathrm{kk}+\mathrm{kl}+\mathrm{kr})] *$ Harga BBM

$$
\begin{aligned}
\text { Gol I } & =69,3224[1+(0,4+0,05+0,035)] * 7600 \\
& =\text { Rp. } 782.372,61 / 1000 \mathrm{~km} \\
\text { Gol II } & =157,038[1+(0,4+0,05+0,035)] * 5150 \\
& =\text { Rp. } 1.200 .988,22 / 1000 \mathrm{~km} \\
\text { Gol III } & =201,593[1+(0,4+0,05+0,035)] * 5150
\end{aligned}
$$

$=$ Rp. $1.541 .732,91 / 1000 \mathrm{~km}$

Gol IV $=201,593[1+(0,4+0,05+0,035)] * 5150$

$=$ Rp. $1.541 .732,91 / 1000 \mathrm{~km}$

Gol V $=201,593[1+(0,4+0,05+0,035)] * 5150$

$=$ Rp. $1.541 .732,91 / 1000 \mathrm{~km}$

Konsumsi Pelumas

Konsumsi Pelumas $=$ Konsumsi pelumas dasar $*$ faktor koreksi

Gol I $=1000 * 0,0033 * 1 * 85000$

$=\mathrm{Rp} 280.500,00 / 1000 \mathrm{~km}$

Gol II $=1000 * 0,0055 * 1 * 40000$

$=\operatorname{Rp} 220.000,00 / 1000 \mathrm{~km}$

Gol III $=1000 * 0,0044 * 1 * 40000$

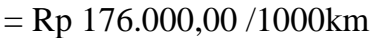

Gol IV $=1000 * 0,0044 * 1 * 40000$

$=\operatorname{Rp} 176.000,00 / 1000 \mathrm{~km}$

Gol V $=1000 * 0,0044 * 1 * 40000$

$=\operatorname{Rp} \operatorname{Rp} 176.000,00 / 1000 \mathrm{~km}$

b. Konsumsi Ban

Konsumsi ban $(\mathrm{Rp} / 1000 \mathrm{~km})$

Gol I $=(0,0008848(73)-0,0045333) * 4 * 732000$

$=$ Rp. $175.847,19 / 1000 \mathrm{~km}$

Gol II $=(0,0012356(61)-0,0064667) * 4 * 1171000$

$=$ Rp. $322.750,55 / 1000 \mathrm{~km}$

Gol III $=(0,0015553(56)-0,0059333) * 6 * 1840000$ $=$ Rp. $896.045,04 / 1000 \mathrm{~km}$

Gol IV $=(0,0015553(56)-0,0059333) 8 * 2750000$ $=$ Rp. $1.785 .597,00 / 1000 \mathrm{~km}$

Gol V $=(0,0015553(56)-0,0059333) 14 * 6650000$ $=$ Rp. $7.556 .321,85 / 1000 \mathrm{~km}$

c. Konsumsi Pemeliharaan (Suku Cadang)

Konsumsi pemeliharaan suku cadang $(\mathrm{Rp} / 1000 \mathrm{~km})$

Gol I $=(0,0000064(73)+0,0005567) * 125000000$ $=$ Rp. $127.987,50 / 1000 \mathrm{~km}$

Gol II $=(0,0000332(61)+0,0020891) * 297400000$ $=$ Rp. $1.223 .592,82 / 1000 \mathrm{~km}$

Gol III $=(0,0000191(56)+0,0015400) * 646000000$ $=$ Rp. $1.685 .801,60 / 1000 \mathrm{~km}$

Gol IV $=(0,0000191(56)+0,0015400) * 680000000$ $=$ Rp. $1.774 .528,00 / 1000 \mathrm{~km}$

Gol V $=(0,0000191(56)+0,0015400) * 876000000$ $=$ Rp. 2.286.009,60 /1000km

d. Konsumsi Pemeliharaan (Jam Kerja Mekanik)

Konsumsi pemeliharaan $(\mathrm{Rp} / 1000 \mathrm{~km})$

Gol I $=0,00362(73)+0,36267 * 15000$ $=$ Rp. $9.414,90 / 1000 \mathrm{~km}$

Gol II $=0,02311(61)+1,97733 * 15000$ $=$ Rp. $50.805,60 / 1000 \mathrm{~km}$

Gol III $=0,01511(56)+1,21200 * 15000$ $=$ Rp. $30.872,40 / 1000 \mathrm{~km}$

Gol IV $=0,01511(56)+1,21200 * 15000$ $=$ Rp. $30.872,40 / 1000 \mathrm{~km}$

Gol V $=0,01511(56)+1,21200 * 15000$ $=\operatorname{Rp} 30.872,40 / 1000 \mathrm{~km}$

e. Depresiasi

Gol I $=1 /(2,5(73)+125) * 1 / 2 * 125000000$ $=$ Rp. $203.252,03 / 1000 \mathrm{~km}$

Gol II $=1 /(9,0(61)+125) * 1 / 2 * 297400000$ $=$ Rp. $148.848,85 / 1000 \mathrm{~km}$

Gol III $=1 /(6,0(56)+125) * 1 / 2 * 646000000$ 


$$
\begin{aligned}
& =\text { Rp. } 507.861,64 / 1000 \mathrm{~km} \\
& \text { Gol IV }=1 /(6,0(56)+125) * 1 / 2 * 680000000 \\
& =\text { Rp. } 534.591,19 / 1000 \mathrm{~km} \\
& \text { Gol V }=1 /(6,0(56)+125) * 1 / 2 * 876000000 \\
& =\operatorname{Rp} 688.679,25 / 1000 \mathrm{~km} \\
& \text { INT }=0,22 \% * \text { Harga kendaraan baru }(\mathrm{Rp} / 1000 \mathrm{~km}) \\
& \text { Gol I }=0,22 \% * 125000000 \\
& =\operatorname{Rp} 275.000,00 \\
& \text { Gol II }=0,22 \% * 297400000 \\
& =\operatorname{Rp} 654.280,00 \\
& \text { Gol III }=0,22 \% * 646000000 \\
& =\operatorname{Rp} 1.421 .200,00 \\
& \text { Gol IV }=0,22 \% * 680000000 \\
& =\operatorname{Rp} 1.496 .000,00 \\
& \text { Gol V }=0,22 \% * 876000000 \\
& =\operatorname{Rp} 1.927 .200,00 \\
& \text { Gol I }=38 /(500(73)) * 125000000 \\
& =\operatorname{Rp} 130.136,99 / 1000 \mathrm{~km} \\
& \text { Gol II }=60 /(2571,42857(61)) * 297400000 \\
& =\operatorname{Rp} 113.759,56 / 1000 \mathrm{~km} \\
& \text { Gol III }=61 /(1714,28571(56)) * 646000000 \\
& =\operatorname{Rp} 410.479,17 / 1000 \mathrm{~km} \\
& \text { Gol IV }=61 /(1714,28571(56)) * 680000000 \\
& =\operatorname{Rp} 432.083,33 / 1000 \mathrm{~km} \\
& \text { Gol V = 61/(1714,28571(56) }) * 876000000 \\
& =\operatorname{Rp} 556.625,00 / 1000 \mathrm{~km}
\end{aligned}
$$

Total BOK = Total Biaya Gerak (konsumsi bahan bakar + konsumsi oli mesin + pemakaian ban + depresiasi) + Total biaya tetap (biaya bunga modal + biaya asuransi).

1. Total BOK Gol. I

$=\operatorname{Rp} 782.372,61+\operatorname{Rp} 280.500,00+R p 175.847,19+R p$

$127.987,50+\operatorname{Rp} 203.252,03+\operatorname{Rp} 9.414,90+\operatorname{Rp} 275.000,00$

$+\operatorname{Rp} 130.136,99$

= Rp. 1.929.875,09

2. BOK gol I per tahun (untuk tahun pertama)

$=$ Total BOK gol I * 365 hari * panjang jalan $/ 1000 \mathrm{Km} *$

Volume

$=\mathrm{Rp} 1.929 .875,09 * 4 \mathrm{~km} / 1000 \mathrm{~km} * 13649176 \mathrm{skr} / \mathrm{tahun}$

= Rp. 105.364.819.022,79/TahunPerhitungan Penghematan

BOK

Penghematan biaya Operasional kendaraan merupakan selisih besarnya nilai BOK pada kondisi without project dan kondisi with project.

\section{Analisa Penghematan Nilai Waktu}

Nilai waktu merupakan besaran sejumlah uang yang dikeluarkan pengguna jalan untuk melakukan satu unit waktu perjalanan [5]. Analisa nilai waktu dilakukan menggunakan metode Bina Marga. Besarnya nilai keuntungan (benefit) dari nilai waktu diperoleh dari perhitungan nilai penghematan (saving) nilai waktu. Untuk mendapatkan nilai penghematan nilai waktu yaitu dengan cara membandingkan nilai waktu sebelum ada LRT (without project) dengan nilai waktu sesudah ada LRT (with project).

Berikut nilai waktu dasar yang digunakan pada Studi ini adalah dari referensi PT. Jasa Marga (1990 - 1996).

Gol I $=\operatorname{Rp~} 12.287 / \mathrm{Jam} /$ Kendaraan

Gol II A $=\operatorname{Rp} 18.534 / \mathrm{Jam} /$ Kendaraan
Gol II B = Rp 13.768/Jam/Kendaraan

Berikut nilai waktu minimum yang digunakan pada Studi ini adalah dari referensi Jasa Marga (DKI Jakarta).

Gol I $=\operatorname{Rp} 8.200 / \mathrm{Jam} /$ Kendaraan

Gol II A $=\operatorname{Rp} 12.369 / \mathrm{Jam} /$ Kendaraan

Gol II B = Rp 9.188/Jam/Kendaraan

Dikarenakan metode tersebut berlaku pada tahun 1996 maka dibutuhkan nilai kaliberasi pada tahun sekarang (2017). Faktor kaliberasi menggunakan perbandingan kurs dollar 1996 dengan kurs dollar 2018 yaitu sebesar 5,8078. Nilai koefisien waktu yang digunakan $\mathrm{k}=1$, mengikuti Jakarta. Sehingga menghasilkan nilai waktu tiap golongannya sebagai berikut:

Gol I = Rp 71.360,5/Jam/Kendaraan

Gol II A = Rp 107.641,86/Jam/Kendaraan

Gol II B = Rp 79.961,86/Jam/Kendaraan

\section{E. Analisa Ekonomi}

Dalam Analisis ini kelayakan dinilai dari parameter NPV (Net Present Value) dan BCR (Benefit Cost Ratio) selama umur rencana. Kedua parameter tersebut didapat dari membandingkan antara nilai manfaat dan biaya pembangunan LRT Cawang - Bekasi Timur. sehingga didapatkan data sebagai berikut :

Biaya Investasi : Rp 7.521.972.632.281,77.

Biaya Pemeliharaan : Rp 150.439.452.645,64

Tingkat Suku Bunga : 7,25\% (BI Rate)

Umur Rencana : 40 Tahun

Inflasi :3,57\% / Tahun

Dari data tersebut dapat dihitung nilai Net Present Value (NPV) dan Benefit Cost Ratio (BCR) dengan hasil sebagai berikut:

h. BCR

Benefit $=\operatorname{Rp} 48.748 .436 .626 .973$

Cost $=$ Rp 9.540.263.214.624

Sehingga didapatkan nilai BCR

$=\frac{\operatorname{Rp} 48.748 .436 .626 .973}{\operatorname{Rp} 9.540 .263 .214 .624}$

$=5,11>1$ (Layak)

i. NPV

$\mathrm{NPV}=$ Benefit - Cost

$=\operatorname{Rp} 48.748 .436 .626 .973-\mathrm{Rp} 9.540 .263 .214 .624=\mathrm{Rp}$

39.208.173.411.349>0 (Layak)

\section{F. Analisa Finansial}

Untuk analisis kelayakan finansial ini ditentukan oleh beberapa indikator yaitu Benefit Cost Ratio (BCR), Net Present Value (NPV), dan Internal Rate of Return (IRR). Untuk perhitungan NPV dan BCR sama dengan analisa ekonomi yang membedakan adalah asal Income/Benefit.

Dalam analisa finansial ini pendapatan yang digunkan untuk menghitung BCR dan NPV adalah pendapatan yang didapat dari pejualan Tiket LRT yang nantinya akan dioperasikan. Harga tiket untuk tiap tujuan disamakan. Harga tiket ditentukan dengan metode Trial and Error dimana harga tiket LRT yang didapatkan disini merupakan harga terendah agar pembangunan LRT bisa layak secara finansial. Sehingga didapatkan harga tiket LRT adalah Rp. 5000,00.

Dari data tersebut dapat dihitung nilai Net Present Value (NPV), Benefit Cost Ratio (BCR) dan Internal Rate of Return (IRR) dengan hasil sebagai berikut: 


\section{j. $\quad$ BCR}

Benefit $=$ Rp 18,359,007,303,801

Cost $=$ Rp 9,540,263,214,624

Sehingga didapatkan nilai BCR

$=\frac{\operatorname{Rp~18,359,007,303,801}}{\operatorname{Rp} 9,540,263,214,624}$

$=1,92>1$ (Layak)

k. NPV

$\mathrm{NPV}=$ Benefit - Cost

$=\operatorname{Rp} 18,359,007,303,801-\operatorname{Rp} 9,540,263,214,624$ $=$ Rp. 8,818,744,089,177 >0 (Layak)

1. IRR

Analisis ini dilakukan dengan cara membandingkan tingkat suku bunga yang menyebabkan nilai NPV $=0$ dan tingkat suku bunga pengembalian terendah MARR (minimum attractive rate of return). Dari hasil perhitungan didapatkan tingkat pengembalian suku

bunga $($ IRR $)=10,98 \%$

IRR $>$ Discount Rate $=7,25 \%$

\section{G. Perencanaan Alinyemen Horizontal}

Untuk rencana analisa perhitungan lengkung horizontal, akan digunakan tipe lengkung Spiral - Circle - Spiral (S - C S) untuk semua tikungan. Direncanakan akan dilewati LRTdengan kecepatan 60-80 km/jam, dengan ketentuan jari jari minimum yang digunakan pada tiap- tiap lengkung yaitu $350 \mathrm{~m}$ dan jari - jari maksimumnya $1650 \mathrm{~m}$.

Untuk mencegah bahaya tergulingnya kereta api maka lengkung horizontal perlu diberi peninggian pada rel bagian luar. Besar peninggian maksimum yang diijinkan untuk lebar jalan rel $1453 \mathrm{~mm}$ adalah hmax $=150 \mathrm{~mm}$. Berdasarkan PM No 60 Tahun 2012, nilai (Lc) harus lebih besar dari 25 meter.

Hasil yang didapat dari perencaan alinyemen horizontal adalah tedapat 18 PI (lengkung). Hasil perhitungan alinyemen horizontal dapat dilihat pada Gambar 1.

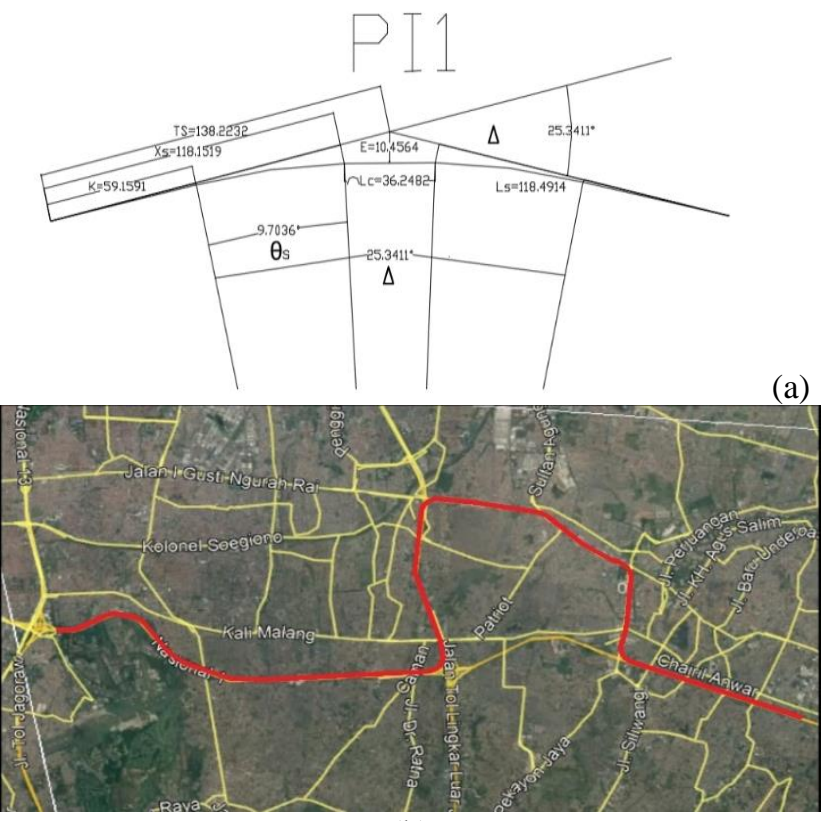

(b)

Gambar 1. a. Lengkung Horizontal (PI 1) Layout b. Perencanaan Alinyemen

\section{H. Perencanaan Alinyemen Vertikal}

Penentuan elevasi tiap - tiap STA dilakukan dengan membagi trase sepanjang $24421 \mathrm{~m}$ setiap $200 \mathrm{~m}$ secara konstan. Berdasarkan perencanaan lengkung Vertikal jalur LRT Cawang - Bekasi Timur didapat hasil jari-jari rencana sebesar 6000 meter dengan kelandaian maksimum sebesar 4\% [6]. Jumlah lengkung vertikal adalah 35 lengkung. Hasil perhitungan alinyemen horizontal dapat dilihat pada Gambar 2.

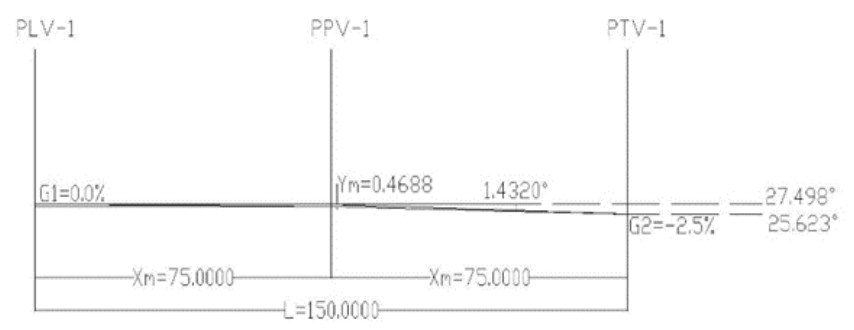

Gambar 2. Lengkung Vertikal (PPV 1).

\section{KESIMPULAN DAN SARAN}

\section{A. Kesimpulan}

Berdasakan hasil analisa dan perhitungan yang dilakuakan di BAB 4 hingga BAB 6, dapat disimpulkan bahwa:

1. Dalam analisa yang dilakukan di BAB 4 tentang volume lalu lintas di jalan tol Jakarta - Cikampek, didapatkan nilai derajat kejenuhan (DJ) untuk kondisi jalan without project dan with project dengan hasil sebagai berikut:

a. Without Project

Bekasi Barat-Cikunir $\quad: 0.930$

Cikunir - Pd. Gede Timur $\quad: 0.874$

Pd. Gede Timur - Pd. Gede Barat : 0.890

Pd. Gede Barat - Cawang $\quad: 0.858$

b. With Project

Bekasi Timur-Bekasi Barat $\quad: 0.375$

Bekasi Barat-Cikunir $\quad: 0.312$

Cikunir - Pd. Gede Timur $\quad: 0.294$

Pd. Gede Timur - Pd. Gede Barat : 0.299

Pd. Gede Barat - Cawang : 0.302

2. Pada BAB 5 dilakukan analisa kelayakan proyek dari aspek ekonomi dan finansial dengan hasil sebagai berikut:

Dari perhitungan penghematan Biaya Operasional

Kendaraan (BOK) didapatkan hasil:

a. Biaya Operasional Kendaraan (BOK) Without Project (2020) : Rp. 1.848.941.840.830,66 /Tahun

b. Biaya Operasional Kendaraan (BOK) With Project (2020) : Rp. 1.740.850.467.312,01/Tahun

c. Penghematan BOK (2020) : BOK Without Project BOK With Project : Rp. 108.091.373.518,65

Dari perhitungan penghematan Nilai Waktu didapatkan hasil:

a. Nilai Waktu Without Project (2020) : Rp. 1.662.828.845.203/Tahun

b. Nilai Waktu With Project (2020) : Rp. 825.490.859.327/Tahun 
c. Nilai Waktu LRT (2020) : Rp. 111.950.273.328 /Tahun

d. Penghematan Nilai Waktu (2020) : Nilai Waktu Without Project - Nilai Waktu With Project - Nilai Waktu LRT : Rp. 725.387.712.547 /Tahun

Dari analisa aspek kelayakan ekonomi didapatkan hasil:

a. Benefit : Rp. 48.748.436.625.973

b. Cost : Rp. 9.540.263.214.624

Dengan hasil perhitungan BCR dan NPV berupa:

a. $\quad$ BCR : Benefit/Cost $=$ Rp. 48.748.436.625.973/Rp. 9.540.263.214.624=5,11>1

b. NPV : Benefit - Cost $=$ Rp. 48.748.436.625.973 Rp. 9.540.263.214.624=Rp 39.208.173.411.349>0

c. Sehingga proyek LRT jabodebek dapat dikatakan LAYAK dari aspek ekonomi.

Dari analisa aspek kelayakan Finansial didapatkan hasil:

a. Benefit : Rp. 18.359.007.303.801

b. Cost : Rp. 9.540.263.214.624

Dengan hasil perhitungan BCR dan NPV berupa:

a. BCR : Benefit $/$ Cost $=$ Rp. 18.359.007.303.801/Rp. 9.540.263.214.624=1,92>1

b. NPV : Benefit - Cost $=$ Rp. 18.359.007.303.801 Rp. 9.540.263.214.624 = Rp. 8.818.744.089.177 >0

c. Dengan nilai Internal Rate of Return (IRR): 10,98\% $>7,25 \%$. Sehingga dapat disimpulkan bahwa pembangunan jalan tol Ciawi - Sukabumi dikatakan LAYAK secara finansial.

3. Dapat dilakukan perencanaan alinyemen pada jalur alternatif LRT Cawang - Bekasi Timur sebagai trase yang dipilih melalui perhitungan Multi Criteria Analysis dengan hasil perhitungan sebagai berikut:

1. Alinyemen Horizontal
Berdasarkan perencanaan lengkung horizontal jalur LRT Cawang - Bekasi Timur didapat hasil kecepatan rencana $80 \mathrm{~km} / \mathrm{jam}$ dengan jari-jari minimum lengkung sebesar 350 meter. Jenis lengkung yang digunakan berupa Circle-Spiral-Circle untuk semua tikungan dengan jumlah tikungan adalah 18 tikungan.

2. Alinyemen Vertikal

Berdasarkan perencanaan lengkung Vertikal jalur LRT Cawang - Bekasi Timur didapat hasil jarijari rencana sebesar 6000 meter dengan kelandaian maksimum sebesar $4 \%$ sesuai dengan tcrp. Jumlah lengkung vertikal adalah 35 lengkung.

\section{B. Saran}

Hasil yang didapat dari analisa kelayakan Ekonomi dan Finansial LRT Cawang - Bekasi Timur adalah LAYAK sehingga diharapkan LRT Cawang - Bekasi Timur dapat segera mengatasi masalah kemacetan yang ada.

\section{DAFTAR PUSTAKA}

[1] Badan Pusat Statistik Provinsi DKI Jakarta, "Transportation Statistic of DKI Jakarta,” Jakarta, 2015.

[2] Kementrian Pekerjaan Umum, "Pedoman Kapasitas Jalan Indonesia," Bandung, 2014.

[3] P. Jinyoung, "Korea's Railway PPP (Public-Private Partnership) Projects," 2014.

[4] Institut of Urban Transport, "Modern Trams (Light Rail Transit)-For Cities in India," New Delhi, 2013.

[5] O. Z. Tamin, Perencanaan dan Pemodelan Transportasi, 2nd ed. Bandung: Institut Teknologi Bandung, 2000.

[6] Transportation Research Board, Transit Cooperative Research Program: Track Design Handbook for Light Rail Transit. Washington D.C.: National Academy Press, 2000. 